Tohoku J. Exp. Med., 2010, 220, 115-120

\title{
High Micronucleus Frequency in Peripheral Blood Lymphocytes of Untreated Cancer Patients Irrespective of Gender, Smoking and Cancer Sites
}

\author{
Olivera Milošević-Djordjević, ${ }^{1,2}$ Darko Grujičić, ${ }^{1}$ Željko Vasković $^{3}$ and \\ Dragoslav Marinković ${ }^{4}$
}

\author{
${ }^{1}$ Faculty of Science, University of Kragujevac, Kragujevac, Serbia \\ ${ }^{2}$ Medical Faculty, University of Kragujevac, Kragujevac, Serbia \\ ${ }^{3}$ Clinical Center Kragujevac, Kragujevac, Serbia \\ ${ }^{4}$ Serbian Academy of Science and Art, Belgrade, Serbia
}

\begin{abstract}
Chromosomal instability could be one of primary causes for malignant cell transformation. The objective of the present study was to evaluate the spontaneous genetic damages in circulated lymphocytes of newly diagnosed cancer patients by using cytokinesis-block micronucleus (CBMN) assay, with respect to the factors that might affect micronucleus frequency (i.e. age, gender, smoking habits and cancer sites). Micronuclei (MN) are small nuclei that are originated from chromosome fragments or whole chromosomes. The analyzed samples included 44 untreated cancer patients (19 females and 25 males with mean age of 60.89 years) with different cancer sites (12 patients with breast cancer, 5 with uterine cancer and 27 with cancer of pharynx). Control group included 40 healthy donors ( 28 females and 12 males with mean age of 43.95 years). The mean baseline MN frequency was significantly higher $(p<0.001)$ in cancer patients $(15.18$ $\pm 5.05 \mathrm{MN} / 1000 \mathrm{BN}$ cells ranging from 4 to 27$)$ than the baseline frequency in healthy controls $(6.45 \pm 2.75$ $\mathrm{MN} / 1000 \mathrm{BN}$ cells, ranging from 1 to 11$)$. There was no gender difference in baseline MN frequency in cancer patients and healthy controls. Moreover, the MN frequency did not significantly differ among cancer sites, and between smokers and non-smokers in both patient and control samples. In conclusion, untreated cancer patients may be associated with an increase of chromosomal instability in peripheral blood lymphocytes, irrespective of gender, cigarette smoking and cancer sites.
\end{abstract}

Keywords: chromosomal instability/micronuclei/peripheral blood lymphocytes/untreated cancer patients/different cancer site

Tohoku J. Exp. Med., 2010, 220 (2), 115-120. C 2010 Tohoku University Medical Press

Different factors are implicated in tumor development process such as exposure to various environmental mutagens/carcinogens i.e. chemical substancies, ionizing and unionizing irradiation, mechanical stimulates, irregular nutrition, cigarette smoking, alcohol consumption, stress, and aging. It is well known and scientifically demonstrated (Radford 2004; Duesberg et al. 2005) that the genetic background of cancer, regarding aging process caused clonal expansion of one single cell which accumulated different mutations during lifetime. Most mutation theories explain the exponential increase of the cancer incidence with age (Renan 1993; Loeb et al. 2003).

Genetic theories showed that specific karyotypic variations of cancer cells were higher in comparison to conventional mutation (Duesberg et al. 2005; Li et al. 2005), and that different types of structural chromosome abnormalities (Johansson et al. 1996) and abnormalities in the chromo- some number of aneuplody type (Duesberg et al. 2004; Soares et al. 2006) are the basis of carcinogenesis.

Micronuclei (MN) are small nuclei that are originated from chromosome fragments or whole chromosomes. Becoming enclosed within a nuclear membrane during cell division, they may be induced by exposure to agents, oxidative stress and genetic defects in the cell cycle (Bonassi et al. 2007). Thus, the validity of the cytokinesis-blocked micronucleus assay (CBMN assay) in peripheral blood lymphocytes is the well established standard method in the evaluation of both chromosomal damage and genome instability in molecular epidemiology and cytogenetics (Fenech 2006). Most of the biomonitoring studies on large populations that evaluated the DNA damage induced by tobacko smoking did not report any association between MN formated in peripheral blood lymphocytes and smoking (Bonassi et al. 2003). A pooled re-analysis from the HUMN

Received October 8, 2009; revision accepted for publication December 2, 2009. doi:10.1620/tjem.220.115

Correspondence:Olivera Milošević-Djordjević, Faculty of Science, University of Kragujevac, Institute of Biology and Ecology, Department of Genetics, Radoja Domanovića 12, P.O. Box 60, 34000 Kragujevac, Serbia.

e-mail: olivera@kg.ac.rs. 
Collaborative Project shows the necessity to discriminate between light smokers ( $<20$ cigarettes/day) and heavy smoker ( $>30$ cigarettes/day). The average number of MN per cell has been shown to differ depending on age and gender of donors and on type of chromosomes (Norppa and Falck, 2003).

Numerous studies showed the association between MN frequency and cancer development. Weichenthal et al. (1989) showed the increase of MN levels in fibroblasts and peripheral blood lymphocytes in the patients affected by familiar cutaneous malignant melanoma. Leal-Garza et al. (2002) confirmed correlation between progresive stages of cervical uterine cancer and MN frequency in cervical epitelium and peripheral blood lymphocytes. More recently, Varga et al. (2006) observed a significant increase of MN level in peripheral blood lymphocytes in breast cancer patients, and Hamurcu et al. (2008) reported the increase of $\mathrm{MN}$ frequency in peripheral lymphocytes of untreated patients with leukemia. Bonassi et al. (2007) concluded that $\mathrm{MN}$ in lymphocytes was a predictive biomarker of cancer risk.

Since cytogenetic studies showed that chromosomal instability could be one of primary causes for malignant cell transformation, the objective of the present study was to investigate the spontaneous genetic damages in circulated lymphocytes of cancer patients and healthy controls by using CBMN assay regarding the factors that might affect $\mathrm{MN}$ frequency (i.e. age, gender, smoking habits and cancer site).

\section{Methods}

\section{Patients}

This study was approved by Ethics Committee of Clinic of Kragujevac (No 01/2577) and consisted of 44 newly diagnosed untreated cancer patients (19 females and 25 males) observed at the Clinical Center in Kragujevac, Serbia, during 2006-2007. The mean age of the patients was 60.89 years, ranging from 42 to 81 years. Out of 44 patients, twelve had breast cancer, five had cancer uteri and twenty seven had cancer of pharynx. All patients were without any therapy and kept standard dietary habit. Four patients were occupationally exposed to known mutagenic agents (Table 1, patients No 1, 17,19 and 20 were exposed to colours, lacquers or lime), and twenty five were smokers $(10<$ cigarettes per day).

Control group included 40 healthy donors ( 28 females and 12 males) aging from 31 to 70 years (mean age 43.95 years) without any recent exposure to known mutagenic agents. Seventeen of 40 persons were smokers $(5<$ cigarettes per day).

\section{Micronucleus test (MNT)}

In our cytogenetic investigation the cytokinesis-block method described by Fenech (1993) was used. Whole heparinised blood (0.5 $\mathrm{ml}$ ) was added into $5 \mathrm{ml}$ of complete medium for the cultivation of cells PBMax Karyotyping (Invitrogen, California, USA). All cultures were set up in duplicate and incubated at $37^{\circ} \mathrm{C}$ up to 72 hours. Cytochalasin B (Sigma, St Louis, MO, USA) was added 44 hours after the beginning of incubation in the final concentration of $4 \mu \mathrm{g} / \mathrm{ml}$. The cultures were incubated for another 28 hours. The cells were centrifuged, washed with $0.9 \% \mathrm{NaCl}$ and treated with hypotonic solution $(0.075 \mathrm{M} \mathrm{KCl})$. The cell suspension was then fixed in methanol: acetic acid $(3: 1)$ three times. The centrifuged cells were resuspended in a small volume of fixative and spread onto specially prepared, cold and lamp-dried slides. The slides were stained with Giemsa solution (2\%) for 10 minutes (Alfapanon, Novi Sad, Serbia).

The MN frequency was determined by analyzing 1000 binucleated cells $(\mathrm{BN})$ per person, according to the criteria described by Fenech (2000).

\section{Statistical significance}

The results were shown as mean \pm standard deviation (s.D.). The mean baseline MN frequencies in lymphocytes of the cancer patients were compared with the mean baseline MN frequencies in healthy control donors using the Student's $t$-test. Levels of significance were $p<0.05, p<0.01$, and $p<0.001$. The difference for cancer types and $\mathrm{MN}$ frequency was determined by using nonparametric Kruskal-Wallis H-test. The relationship between age, gender, smoking habits, cancer site and MN frequency was determined by Spearman correlation coefficients.

\section{Results}

Table 1 shows general and lifestyle characteristics of cancer patients as well as their individual baseline MN values.

In Table 2, the mean MN frequencies and range of $\mathrm{MN}$ in different group of examined untreated patients and controls are reported. Statistical analysis showed significantly higher baseline $\mathrm{MN}$ frequencies in the cancer patients in comparison to healthy controls $(15.18 \pm 5.05 \mathrm{MN} / 1000 \mathrm{BN}$ cells, ranging from 4 to 27 vs. $6.45 \pm 2.75 \mathrm{MN} / 1000 \mathrm{BN}$ cells, ranging from 1 to 11 ), with probability $p<0.001$. In the sample of cancer patients, baseline MN frequencies were $14.36 \pm 5.22$ per $1000 \mathrm{BN}$ cells for males and $16.26 \pm$ 4.74 per $1000 \mathrm{BN}$ cells for females. In the controls, the baseline MN values were $6.85 \pm 2.34$ per $1000 \mathrm{BN}$ cells for males, and $6.26 \pm 2.94$ per $1000 \mathrm{BN}$ cells for females. The MN values did not differ significantly between smokers and non-smokers in both patients and controls $(p>0.05)$. In all samples, age had no statistically significant effect on the $\mathrm{MN}$ value rates $(p>0.05)$. The $\mathrm{MN}$ frequency among different cancer types was not significantly different $\left[\mathrm{H}_{\mathrm{df} 2, \mathrm{~N}=44}\right.$ $=0.635, p>0.05]$.

Table 3 shows the results of MN distribution in the analyzed binucleated cells. Cells with $1 \mathrm{MN}$ were predominant in both patient and control samples. Out of 44000 analyzed binucleated cells in cancer patients, 551 cells $(1.25 \%)$ had $1 \mathrm{MN}$, the frequency of which was higher than in controls (258 cells, i.e. $0.65 \%$ ). Cells with $2 \mathrm{MN}$ were less common ( 39 cells i.e. $0.09 \%$ in patients vs. 3 cells i.e. $0.01 \%$ in controls), while the cells with $3 \mathrm{MN}$ were found only in patients samples ( 13 cells, i.e. $0.03 \%)$.

The results of correlation analysis between age, cancer site and $\mathrm{MN}$ frequency were negative $(r=-0.104, p=0.503$; $r=-0.089, p=0.565)$. The correlations between gender, smoking habits and MN frequency were found, but without statistical significance $(r=0.145, p=0.347 ; r=0.294, p=$ 
Table 1. General characteristics and micronuclei frequency in cancer patients.

\begin{tabular}{|c|c|c|c|c|c|c|c|}
\hline No & $\begin{array}{l}\text { Age } \\
\text { (years) }\end{array}$ & Sex & Cancer site & Occupation & Smoking status & $\begin{array}{c}\text { No of cigarettes/ } \\
\text { day }\end{array}$ & $\begin{array}{l}\text { MN/1000 } \\
\text { BN cells }\end{array}$ \\
\hline 1. & 64 & $\mathrm{~F}$ & breast & painter & - & - & 9 \\
\hline 2. & 49 & F & breast & employee & + & 20 & 16 \\
\hline 3. & 56 & $\mathrm{~F}$ & breast & employee & + & 10 & 23 \\
\hline 4. & 42 & $\mathrm{~F}$ & breast & hairdresser & - & - & 8 \\
\hline 5. & 60 & $\mathrm{~F}$ & breast & cook & - & - & 19 \\
\hline 6. & 63 & $\mathrm{~F}$ & breast & nurse & - & - & 18 \\
\hline 7. & 46 & $\mathrm{~F}$ & breast & hygienist & + & 20 & 24 \\
\hline 8. & 42 & $\mathrm{~F}$ & breast & charwoman & + & 10 & 15 \\
\hline 9. & 71 & $\mathrm{~F}$ & breast & pensioner & - & - & 16 \\
\hline 10. & 62 & $\mathrm{~F}$ & breast & teacher & - & - & 12 \\
\hline 11. & 54 & $\mathrm{~F}$ & breast & architect & - & - & 15 \\
\hline 12. & 53 & $\mathrm{~F}$ & breast & hairdresser & - & - & 12 \\
\hline 13. & 54 & $\mathrm{~F}$ & uterus & employee & + & 20 & 24 \\
\hline 14. & 68 & $\mathrm{~F}$ & uterus & pensioner & - & - & 13 \\
\hline 15. & 60 & $\mathrm{~F}$ & uterus & farmer & - & - & 15 \\
\hline 16. & 56 & $\mathrm{~F}$ & uterus & unemployed & - & - & 15 \\
\hline 17. & 57 & $\mathrm{~F}$ & uterus & painter & + & 10 & 18 \\
\hline 18. & 51 & $\mathrm{M}$ & pharynx & seller of paints & + & 20 & 20 \\
\hline 19. & 60 & M & pharynx & worker/glue & + & 60 & 18 \\
\hline 20. & 59 & $\mathrm{M}$ & pharynx & worker/glue & + & 20 & 13 \\
\hline 21. & 64 & $\mathrm{M}$ & pharynx & pensioner & + & 40 & 15 \\
\hline 22. & 74 & $\mathrm{M}$ & pharynx & farmer & + & 20 & 12 \\
\hline 23. & 54 & $\mathrm{M}$ & pharynx & driver & + & 20 & 17 \\
\hline 24. & 58 & $\mathrm{~F}$ & pharynx & pensioner & - & - & 14 \\
\hline 25. & 79 & M & pharynx & farmer & - & - & 6 \\
\hline 26. & 60 & $\mathrm{M}$ & pharynx & technician & + & 20 & 16 \\
\hline 27. & 66 & $\mathrm{~F}$ & pharynx & pensioner & - & - & 23 \\
\hline 28. & 51 & $\mathrm{M}$ & pharynx & unemployed & + & 30 & 18 \\
\hline 29. & 54 & $\mathrm{M}$ & pharynx & unemployed & + & 30 & 16 \\
\hline 30. & 58 & M & pharynx & farmer & + & 40 & 4 \\
\hline 31. & 75 & $\mathrm{M}$ & pharynx & pensioner & + & 35 & 17 \\
\hline 32. & 78 & M & pharynx & employee & + & 20 & 19 \\
\hline 33. & 75 & $\mathrm{M}$ & pharynx & pensioner & + & 20 & 27 \\
\hline 34. & 56 & $\mathrm{M}$ & pharynx & farmer & + & 50 & 19 \\
\hline 35. & 52 & $\mathrm{M}$ & pharynx & employee & - & - & 12 \\
\hline 36. & 67 & M & pharynx & pensioner & - & - & 14 \\
\hline 37. & 76 & $\mathrm{M}$ & pharynx & farmer & + & 20 & 11 \\
\hline 38. & 54 & $\mathrm{M}$ & pharynx & employee & + & 20 & 8 \\
\hline 39 & 61 & $\mathrm{M}$ & pharynx & pensioner & - & - & 7 \\
\hline 40. & 81 & $\mathrm{M}$ & pharynx & farmer & - & - & 19 \\
\hline 41. & 61 & M & pharynx & unemployed & + & 30 & 15 \\
\hline 42. & 73 & $\mathrm{M}$ & pharynx & pensioner & - & - & 14 \\
\hline 43. & 54 & $\mathrm{M}$ & pharynx & unemployed & + & 25 & 15 \\
\hline 44. & 71 & M & pharynx & pensioner & + & 20 & 7 \\
\hline
\end{tabular}

$0.053)$.

\section{Discussion}

Genetic instability was associated with the initiation and progresion of cancer in many reports (Yan et al. 2005; Bonassi et al. 2007); it ocurred mainly as the consequence of either missegregation of normal chromosomes or structural rearrangement (Muleris et al. 2008) in both cancer 
Table 2. Micronuclei frequency in peripheral blood lymphocytes of cancer patients and healthy controls.

\begin{tabular}{|c|c|c|}
\hline \multirow{2}{*}{ Data about blood sampling } & \multicolumn{2}{|c|}{ Mean $\mathrm{MN} \pm$ s.D. $/ 1000 \mathrm{BN}$ cells (range) } \\
\hline & Cancer patients & Controls \\
\hline \multicolumn{3}{|l|}{ Total } \\
\hline Mean MN & $15.18 \pm 5.05(4-27)^{\mathrm{a}}$ & $6.45 \pm 2.75(1-11)$ \\
\hline Age (years) & $60.89 \pm 9.79(42-81)$ & $43.95 \pm 11.08(31-70)$ \\
\hline \multicolumn{3}{|l|}{ Sex } \\
\hline Males & $14.36 \pm 5.22(4-27)^{\mathrm{b}}$ & $6.85 \pm 2.34(3-10)^{\mathrm{c}}$ \\
\hline Females & $16.26 \pm 4.74(8-24)$ & $6.26 \pm 2.94(1-11)$ \\
\hline \multicolumn{3}{|l|}{ Smoking status } \\
\hline Smoker & $16.28 \pm 5.35(4-27)^{\mathrm{d}}$ & $6.12 \pm 2.85(1-11)^{\mathrm{e}}$ \\
\hline Non-smoker & $13.74 \pm 4.34(6-23)$ & $6.69 \pm 2.70(1-10)$ \\
\hline \multirow[t]{2}{*}{ Age groups } & $15.76 \pm 4.76(40-60 \text { years })^{\mathrm{f}}$ & $6.10 \pm 3.03(30-40 \text { years })^{g}$ \\
\hline & $14.42 \pm 5.44(61-81$ years $)$ & $6.83 \pm 2.38(41-71$ years $)$ \\
\hline \multicolumn{3}{|l|}{ Cancer site } \\
\hline Breast $(N=12)$ & $15.58 \pm 4.96(8-24)$ & \\
\hline Uterus $(N=5)$ & $17.00 \pm 4.30(13-24)$ & \\
\hline Pharynx $(N=27)$ & $14.67 \pm 5.28(4-27)^{\mathrm{h}}$ & \\
\hline t-test & \multicolumn{2}{|c|}{$\begin{array}{l}t=9.92, p<0.001^{\mathrm{a}} t=1.25, p>0.05^{\mathrm{b}} t=0.68, p>0.05^{\mathrm{c}} t=1.74, \\
p>0.05^{\mathrm{d}} t=0.48, p>0.05^{\mathrm{e}} t=0.08, p>0.05^{\mathrm{f}} t=0.10, p>0.05^{\mathrm{g}}\end{array}$} \\
\hline Kruskal-Wallis H-test & \multicolumn{2}{|l|}{$H=0.635, p>0.05^{\mathrm{h}}, \mathrm{df}=2$} \\
\hline
\end{tabular}

${ }^{a}$ statistically significant difference in mean frequency of MN between cancer patients and healthy controls

b,c no significant difference in mean frequency of MN between male and female in cancer patients and healthy controls

$\mathrm{d}, \mathrm{e}$ no significant difference in mean frequency of MN between smokers and nonsmokers in cancer patients and healthy controls

${ }^{\mathrm{f}, \mathrm{g}}$ no significant difference in mean frequency of $\mathrm{MN}$ between age groups in cancer patients and healthy controls

${ }^{\mathrm{h}}$ no significant difference in mean frequency of $\mathrm{MN}$ between different cancer sites

Table 3. Distribution of micronuclei frequency in analyzed patients and healthy controls.

\begin{tabular}{|c|c|c|c|c|c|c|}
\hline \multirow{2}{*}{ Sample } & \multirow{2}{*}{$\mathrm{MN} \pm$ s.D. $/ 1000 \mathrm{BN}$ cells } & \multirow{2}{*}{$\begin{array}{l}\text { Analyzed } \\
\text { cells }\end{array}$} & \multirow{2}{*}{$\begin{array}{c}\text { Range } \\
\text { variation }\end{array}$} & \multicolumn{3}{|c|}{ Distribution of MN/cell } \\
\hline & & & & $1 \mathrm{MN}$ & $2 \mathrm{MN}$ & $3 \mathrm{MN}$ \\
\hline Cancer patients & $15.18 \pm 5.05$ & 44000 & $4-27$ & $551(1.25 \%)$ & $39(0.09 \%)$ & $13(0.03 \%)$ \\
\hline Controls & $6.45 \pm 2.75$ & 40000 & $1-11$ & $258(0.65 \%)$ & $3(0.01 \%)$ & $0(0.00 \%)$ \\
\hline
\end{tabular}

cells as the target cells and peripheral lymphocytes as surrogate target cells (Bonassi et al. 2008). For years, lymphocytes can circulate through different organs accumulating DNA damages; therefore, chromosomal damages in lymphocytes are a relevant biomarker of health risk in humans (Lou et al. 2007).

Chromosomal aberrations may be the result of defects of mitotic spindle, abnormal centrosome formation and failure of cytokinesis, when they grow into missegregation, or may be caused by failure in the repair of DNA, when they grow into structural chromosome aberrations. MN assay has been extensively used to screen individuals exposed to various mutagenic agents and to study genetic damage among individuals (Fenech et al. 1999). The fact that the MN occurs as a result of numerical and structural chromo- some aberrations reflecting the degree of genetic instability was reported by different authors (Mateuca et al. 2006; Zalacain et al. 2006; Murgia et al. 2008). Therefore, among the cancer risk biomarkers, MN had attracted great interest (Bonassi et al. 2007).

The aim of the present study was to evaluate the frequency of MN by using CBMN assay in peripheral blood lymphocytes in untreated newly diagnosed cancer patients and in healthy controls of both genders. The results showed significantly higher baseline MN values in peripheral blood lymphocytes in patients (cancer site: breast, uterus and pharinx) in comparison to controls. The baseline frequency of $\mathrm{MN}$ in cancer patients ranged from 4 to 27 , while in the healthy controls it was from 1 to 11 . Most authors reported variability of baseline $\mathrm{MN}$ values in healthy controls with 
mean value of $\sim 10 \mathrm{MN}$ per $1000 \mathrm{BN}$ lymphocytes (ranging from 4 to 15), which could be affected by different factors such as lifestile, various medical therapies and climatic changes (Fenech 1993; Duffaund et al. 1997). Fenech (2000) concluded that the number of MN in a single binucleated cell normally ranges from 0 to 3 in lymphocytes of healthy individuals.

The data presented here show significant increase of binucleated cells with more than $1 \mathrm{MN} / \mathrm{BN}$ cell in patients in comparison to controls, while the cells with $3 \mathrm{MN}$ per cell were found only in patients $(13 / 44000 \mathrm{BN}$ cells, i.e. $0.03 \%)$.

The genetic instability in peripheral blood lymphocytes based on the state of health (cancer/health) was found in the results of several authors. Lou et al. (2007) studied spontaneous and ionizing irradiation induced genetic damage in peripheral blood lymphocytes of lung cancer patients by using two indicators, frequency of micronucleated cells and the MN frequency. They observed significant increase of genetic instability in the lymphocytes of patients in comparison to controls. Varga et al. (2006) reported significant difference between breast cancer patients and female controls. Studying the structural chromosome aberrations and aneuploidy, Bonassi et al. (2001) showed causal association between MN frequency and cancer risk.

It is not clear whether the increase of MN frequency is due to cancer development. It is possible that $\mathrm{MN}$ frequency before the onset of cancer was normal, but it increased after the beginning of the disease and could be a consequence of the disease status.

Our results show that $\mathrm{MN}$ were increased from 2.1 to $\sim 2.5$ fold in comparison to mean value in healthy controls in all the examined cancer cases, regardless to the cancer sites. Murgia et al. (2008), who studied the association between $\mathrm{MN}$ increase and cancer death risk using the sample of 52 cancer patients, did not find any correlation between MN frequency and cancer site. They found MN increased from 2.5 to 3.5 times over the control level for the studied cancer sites (digestive and oral cavity, respiratory, genito-urinary, breast, lymphoma and encephalon).

Among the factors that may affect MN frequency, state of health, gender, age and smoking habits in both patient and control samples were investigated. Our results showed that only state of health i.e. events which occurred in etiology of cancer, influenced the micronucleus rates $(r=0.738$, $p=0.00)$. In the studied population, there was no significant difference between smokers and nonsmokers in both patient and control samples $(p>0.05)$.

The effect of smoking habits was evaluated in a large number of biomonitoring studies of occupationally and environmentally exposed and non-exposed populations. The large majority of studies did not find any correlation between MN and smoking (Thierens et al. 2000; Touil et al. 2002; Bonassi et al. 2003). The effect of cigarette smoking on the MN frequency was also evaluated in cancer patients. Thus, Duffaund et al. (1997) and Yildirim et al. (2006) reported no significant difference between $\mathrm{MN}$ values in smokers and non-smokers in the studied cancer patients. Our results show that cigarette smoking did not affect the $\mathrm{MN}$ frequency in any cancer patients and any healthy controls.

Our results show that gender and age did not affect baseline $\mathrm{MN}$ frequency in analyzed cancer patients and healthy controls. These results are in agreement with the results reported by Duffaund et al. (1997), who investigated the effect of gender, age and smoking habits, concluded that age and gender did not significantly affect the frequency of MN. In cancer patients, classified into two age groups (40 60 years and $61-81$ years), the age had no statistically significant effect on lymphocyte MN. In healthy donors, the MN frequency increases with age (age groups 28 - 40 and 41 - 71 years), but without statistical significance $(p>0.05)$. Similar results were reported by several authors (Arlett et al. 1989; Duffaund et al. 1997; Hamurcu et al. 2008). In our patients (consisting of $\sim 43 \%$ females), and in controls (consisting of $70 \%$ females), gender had no significant effect on the analyzed MN frequency. This finding is in agreement with previous reports where the influence of gender on MN was studied and no correlation was found (Arlett et al. 1989; Yildirim et al. 2006).

The use of Spearman correlation showed that no significant relationship was found between age, gender, cigarette smoking, cancer site and $\mathrm{MN}$ frequency, and that the affected MN frequency in lymphocytes of patients may be only in the etiology of cancer.

Since in circulating lymphocytes, MN contain chromosomal fragments or chromosomes resulting from direct DNA breakage, inhibition of DNA template and deficiency of DNA repair capacity, we conclude that the increase of baseline MN frequency in circulating lymphocytes of untreated cancer patients corresponds to the increase of chromosomal damage that occurs due to disease-related changes. Our results suggest that the MN frequency in lymphocyte may be a relevant biomarker for the predisposition and diagnosis of cancer.

\section{Acknowledgments}

The study was supported by the Ministry of Science of Serbia, Grant No. 143008.

\section{References}

Arlett, C., Ashby, J., Fielder, R.J. \& Scott, D. (1989) Micronuclei: origins, applications and methodologies-a workshop sponsored by the Health and Safety Executive held in Manchester, May 23-25, 1988. Mutagenesis, 4, 482-485.

Bonassi, S., Fenech, M., Lando, C., Lin, Y.P., Ceppi, M., Chang, W.P., Holland, N., Kirsh-Volders, M., Zeiger, E., Ban, S. Barale, R., Bigatti, M.P., Bolognesi, C., Jia, C., Di Giorgio, M., Ferguson, L.R., Fucic, A., Lima, O.G., Hrelia, P., Krishnaja, A.P., Lee, T.K., Migliore, L., Mikhalevich, L., Mirkova, E., Mosesso, P., Müller, W.U., Odagiri, Y., Scarffi, M.R., Szabova, E., Vorobtsova, I., Vral, A. \& Zjino, A. (2001) Human MicroNucleus project: international database comparison for results with the cytokinesis-block micronucleus assay in human lym- 
phocytes: I. Effect of laboratory protocol, scoring criteria and host factors on the frequency of micronuclei. Environ. Mol. Mutagen., 37, 31-45.

Bonassi, S., Neri, M., Lando, C., Ceppi, M., Lin, Y., Chang, W.P., Holland, N., Kirsch-Volders, M., Zeiger, E. \& Fenech, M.; the HUMN collaborative group. (2003) Effect of smoking habit on the frequency of micronuclei in human lymphocytes: results from the Human MicroNucleus project. Mutat. Res., 543, 155-166.

Bonassi, S., Norppa, H., Ceppi, M., Srtömberg, U., Vermeulen, R., Znaor, A., Cebulska-Wasilewska, A., Fabianova, E., Fucic, A., Gundy, S., Hansteen, I.L., Knudsen, L.E., Lazutka, J., Rossner, P., Sram, R.J. \& Boffetta, P. (2008) Chromosomal aberration frequency in lymphocytes predicts the risk of cancer: results from a pooled cohort study of 22358 subjects in 11 countries. Carcinogenesis, 29, 1178-1183.

Bonassi, S., Znaor, A., Ceppi, M., Lando, C., Chang, W.P., Holland, N., Kirsch-Volders, M., Zeiger, E., Ban, S., Barale, R., Bigatti, M.P., Bolognesi, C., Cebulska-Wasilewska, A., Fabianova, E., Fucic, A., Hagmar, L., Joksic, G., Martelli, A., Migliore, L., Mirkova, E., Scarfi, M.R., Zijno, A., Norppa, H. \& Fenech, M. (2007) An increased micronucleus frequency in peripheral blood lymphocytes predicts the risk of cancer in humans. Carcinogenesis, 28, 625-631.

Duesberg, P., Fabarius, A. \& Hehlmann, R. (2004) Aneuploidy, the primary cause of the multilateral genomic instability of neoplastic and preneoplastic cells. IUBMB Life, 56, 65-81.

Duesberg, P., Li, R., Fabarius, A. \& Hehlmann, R. (2005) The chromosomal basis of cancer. Cell. Oncol., 27, 293-318.

Duffaund, F., Orsière, T., Villani, P., Pelissier, A.L., Volot, F., Favre, R. \& Botta, A. (1997) Comparison between micronucleated lymphocyte rates observed in healthy subjects and cancer patients. Mutagenesis, 12, 227-231.

Fenech, M. (1993) The cytokinesis-block micronucleus technique: a detailed description of the method and its application to genotoxicity studies in human populations. Mutat. Res., 285, $35-44$.

Fenech, M. (2000) The in vitro micronucleus technique. Mutat. Res., 455, 81-95.

Fenech, M. (2006) Cytokinesis-block micronucleus assay evolves into a "cytome" assay of chromosomal instability, mitotic dysfunction and cell death. Mutat. Res., 600, 58-66.

Fenech, M., Holland, N., Chang, W.P., Zeiger, E. \& Bonassi, S. (1999) The Human Micro Nucleus Project-An international collaborative study on the use of the micronucleus technique for measuring DNA damage in humans. Mutat. Res., 428, 271-283.

Hamurcu, Z., Dönmez-Altuntas, H. \& Patiroglu, T. (2008) Basal level micronucleus frequency in stimulated lymphocytes of untreated patients with leukemia. Cancer Genet. Cytogenet., 180, $140-144$

Johansson, B., Mertens, F. \& Mitelman, F. (1996) Primary vs. secondary neoplasia-associated chromosomal abnormalities-balanced rearrangements vs. genomic imbalances? Genes Chromosomes Cancer, 16, 155-163.

Leal-Garza, C.H., Cerda-Flores, R.M., Leal-Elizondo, E. \& CortésGutiérrez, E.I. (2002) Micronuclei in cervical smears and peripheral blood lymphocytes from women with and without cervical uterine cancer. Mutat. Res., 515, 57-62.

Li, R., Hehlmann, R., Sachs, R. \& Duesberg, P. (2005) Chromosomal alterations cause the high rates and wide ranges of drug resistance in cancer cells. Cancer Genet. Cytogenet., 163,
44-56.

Loeb, L.A., Loeb, K.R. \& Anderson, J.P. (2003) Multiple mutations and cancer. Proc. Natl. Acad. Sci. USA, 100, 776-781.

Lou, J., He, J., Zheng, W., Jin, L., Chen, Z., Chen, S., Lin, Y. \& Xu, S. (2007) Investigating the genetic instability in the peripheral lymphocytes of 36 untreated lung cancer patients with comet assay and micronucleus assay. Mutat. Res., 617, 104-110.

Mateuca, R., Lombaert, N., Aka, P.V., Decordier, I. \& Kirsch-Volders, M. (2006) Chromosomal changes: induction, detection methods and applicability in human biomnitoring. Biochimie, 88, 1515-1531.

Muleris, M., Chalastanis, A., Meyer, N., Lae, M., Dutrillaux, B., Sastre-Garau, X., Hamelin, R., Flejou, J.F. \& Duval, A. (2008) Chromosomal instability in near-diploid colorectal cancer: a link between numbers and structure. PLoS One, 3, e1632.

Murgia, E., Ballardin, M., Bonassi, S., Rossi, A.M. \& Barale, R. (2008) Validation of micronuclei frequency in peripheral blood lymphocytes as early cancer risk biomarker in a nested case-control study. Mutat. Res., 639, 27-34.

Norppa, H. \& Falck, G.C. (2003) What do human micronuclei contain? Mutagenesis, 18, 221-233.

Radford, I.R. (2004) Chromosomal rearrangement as the basis for human tumourigenesis. Int. J. Radiat. Biol., 80, 543-557.

Renan, M.J. (1993) How many mutations are required for tumorigenesis? Implications from human cancer data. Mol. Carcinog., 7, 139-146.

Soares Leite, D., Lima de Lima, P.D., Ferreira Leal, M., Suchi Chen, E., Casartelli, C., de Arruda Cardoso Smith, M. \& Rodriguez Burbano, R. (2006) Investigation of chromosome 21 aneuploidies in breast fibroadenomas by fluorescence in situ hybridisation. Clin. Exp. Med., 6, 166-170.

Thierens, H., Vral, A., Morthier, R., Aousalah, B. \& De Ridder, L. (2000) Cytogenetic monitoring of hospital workers occupationally exposed to ionizing radiation using the micronucleus centromere assay. Mutagenesis, 15, 245-249.

Touil, N., Aka, P.V., Buchet, J.P., Thierens, H. \& Kirsch-Volders, M. (2002) Assessment of genotoxic effects related to chronic low dose level exposure to ionizing radiations using biomarkers for DNA damage and repair. Mutagenesis, 17, 223-232.

Varga, D., Hoegel, J., Maier, C., Jainta, S., Hoehne, M., Patino-Garcia, B., Michel, I., Schwarz-Boeger, U., Kiechle, M., Kreienberg, R. \& Vogel, W. (2006) On the difference of micronucleus frequencies in peripheral blood lymphocytes between breast cancer patients and controls. Mutagenesis, 21, 313-320.

Weichenthal, M., Roser, M., Ehlert, U., Frenzer, S., Breitbart, E. \& Rüdiger, H.W. (1989) Increased numbers of spontaneous micronuclei in blood lymphocytes and cultures fibroblasts of individuals with familial cutaneous malignant melanoma. $J$. Cancer Res. Clin. Oncol., 115, 264-268.

Yan, W., Song, L., Wei, W., Li, A., Liu, J. \& Fang, Y. (2005) Chromosomal abnormalities associated with neck nodal metastasis in nasopharyngeal carcinoma. Tumour Biol., 26, 306-312.

Yildirim, I.H., Yesilada, E. \& Yologlu, S. (2006) Micronucleus frequency in peripheral blood lymphocytes and exfoliated buccal cells of untreated cancer patients. Genetika, 42, 705-710.

Zalacain, M., Sierrasesumaga, L., Larrannaga, C. \& PatinnoGarcia, A. (2006) Effects of benzopyrene-7,8-diol-9,10-epoxide (BPDE) in vitro and of maternal smoking in vivo on micronuclei frequencies in fetal cord blood. Pediatr. Res., 60 , 180-184. 